Summer 2013

\title{
Private Governance of Knowledge: Societally-Crafted Intellectual Properties Regimes
}

Dan Wielsch

University of Cologne

Follow this and additional works at: https://www.repository.law.indiana.edu/ijgls

Part of the Constitutional Law Commons, Intellectual Property Law Commons, and the International Law Commons

\section{Recommended Citation}

Wielsch, Dan (2013) "Private Governance of Knowledge: Societally-Crafted Intellectual Properties Regimes," Indiana Journal of Global Legal Studies: Vol. 20 : Iss. 2 , Article 12.

Available at: https://www.repository.law.indiana.edu/ijgls/vol20/iss2/12

This Symposium is brought to you for free and open access by the Law School Journals at Digital Repository @ Maurer Law. It has been accepted for inclusion in Indiana Journal of Global Legal Studies by an authorized editor of Digital Repository @ Maurer Law. For more information, please contact rvaughan@indiana.edu.

\section{$\Psi$}

JEROME HALL LAW LIBRARY

INDIANA UNIVERSITY

Maurer School of Law
Bloomington 


\title{
Private Governance of Knowledge: Societally-Crafted Intellectual Properties Regimes
}

\author{
DAN WIELSCH*
}

\begin{abstract}
The evolutionary challenge global society faces is the decentralized development of legal rules that multilaterally protect social autonomies from violating each other. At the national level, democratic constitutions provide for the resolution of conflicts between different normative worlds, although the focus here is certainly on the protection of autonomies from political encroachment. However, political constitutions make sure that legal orders consider a plurality of normative perspectives. In contrast, international lawmaking can exclusively link to a specific social rationality, lacking any impartial forum for normative reconciliation. This is of special importance for the governance of intellectual resources. The incorporation of international intellectual property protection into the framework of trade relations has resulted in a unilateral economic interpretation of intellectual property (IP) rights. This biased international IP lawmaking does not satisfy the demands of knowledge production in society and the various types of social interaction requiring the use of copyrighted material, as the increasing number of privately-crafted IP regimes indicates. These private regimes reconfigure property rights in a way that is reflective of the environmental conditions of knowledge-sharing in social systems. As it seems, constitutionalization of global knowledge-sharing must take place through the recognition of the jurisgenerative power of societal rule production together with the public role of private law in the judicial review of private ordering. Under conditions of normative fragmentation, the constitution gets dispersed into ecological integrity rules that take account of the multilateral social effects of rights.
\end{abstract}

* Professor of Law, University of Cologne; LL.M Berkeley 2003; Dr. iur. Frankfurt/M. 1999.

Indiana Journal of Global Legal Studies Vol. 20, Issue 2 (2013)

(C) Indiana University Maurer School of Law 


\section{INTRODUCTION}

At the global level, the legitimacy of law cannot be established in the same way as it is at the national level. In the latter instance, an impartial justification of legal norms is supposed to be achieved through procedural universality, which is characteristic of democratic legislation and which makes possible the equal consideration of all interests involved. And only here, the juridification of social spheres must comply with the higher norms of a constitution, and the impact of specialized legal regimes on the individual is moderated by coordination with other legal regimes that protect different values and different types of social interaction.

To be sure, the global world is not devoid of state-made law. For instance, there is a huge body of international treaties on intellectual property (IP) that regulate the use of intellectual resources on a global scale and thereby impact knowledge-sharing in various fields of creative activity (infra Part I). Yet, without procedural guarantees for considering a diversity of perspectives and plural values, international IP legislation can exclusively link to a specific social system. So, when faced with the increasing economic importance of copyright industries on the one side, and the concern about massive copyright infringement activities on the Internet on the other side, the leading industrial nations decided that these challenges could best be answered by subsuming international IP protection under the framework of trade relations. This linking resulted in a mono-functional interpretation of IP rights according to economic rationality since the trade regime is biased in favor of economic interests and does not give equal weight to other normativities. Absent the force of the constitution, state law is seemingly prone to lacking the normative multilateralism required in modern differentiated society. There is strong evidence that international IP treaties do not satisfy the demands of knowledge production in society and the various types of social interaction requiring the use of copyrighted material. ${ }^{1}$ This diagnosis holds true not only for copyright law, but applies also to other areas of IP law experiencing the emergence of open licensing-a development that indicates the need for alternative configurations of user freedoms.

However, the present discontent about IP law in various sectors of civil society cannot just be blamed on the shrinking influence of national constitutions. The political constitution as such is designed to control

1. See, e.g., Jerome H. Reichman \& Ruth L. Okediji, When Copyright Law and Science Collide: Empowering Digitally Integrated Research Methods on a Global Scale, 96 MiNN. L. REv. 1362, 1370 (2012) (diagnosing "a growing conflict between private rights and public goods at the core of today's most promising research techniques."). 
the activities of a central lawmaker. It leaves open the question of governing rules for autonomous social rationalities other than the organized political system. As the approach of "societal constitutionalism" points out, the issue of how to limit social autonomies from expanding their specific rationalities to the detriment of other autonomies has been neglected in the past (infra Part II). ${ }^{2}$ Given that the primary function of constitutions in the traditional sense is to constitute an effective realm for political decision-making in society and at the same time to restrain political power from encroaching on social autonomies, the focus was certainly on the protection and the furtherance of social autonomies. This development was the very intent of the liberal distinction between state and society. As a matter of consequence, the question of limitation of social autonomies vis-à-vis each other was either left unattended or was redirected to the state in the hope that it would be able to integrate the centrifugal forces of differentiated society. Aside from the fact that the latter option is not available at the global level because state regulation is inherently restrained by the principle of sovereignty, this strategy always neglected the capacity of institutions to enable social cooperation. Mesmerized by Hobbes' take on the problem of social order, political philosophy in the genealogy of constructivist rationalism misunderstood the grammar of social institutions and underrated the possibilities of a decentralized generation of order. In contrast, an epistemological analysis of property rights suggests that decentralized decision-making generates patterns of practical knowledge for social coordination. Rather in line with Hume, legal rules must be seen to evolve as the result of practical experience and social standards. ${ }^{3}$

These effects must not be taken for granted, though. They depend on the constitutional awareness of private law in finding rules ensuring that private actors, while autonomously pursuing their own interests, do so simultaneously in the general interest. Such rules were developed, for example, in the form of competition law, which constitutionalizes the process of economic competition. As will be argued, global society faces the evolutionary challenge of developing rules that multilaterally protect autonomies from violating each other. In the realm of intellectual goods, the specific difficulty for constitutionalization of knowledge sharing can only be grasped with the help of a relational account of IP rights that acknowledges the interdependencies between the communicative activity of the individual and the respective cultural

2. See Gunther Teubner, Constitutional Fragments: Societal ConstTtutionalism AND GLOBALIZATION 10 (2012).

3. See F. A. HaYeK, The Legal and Political Philosophy of David Hume, in STUdIES IN PHILOSOPHY, POLITICS AND ECONOMICS 106 (1967) (emphasizing this point). 
spheres of meaning (infra Part III). The essential means by which the law reflects on the environmental conditions of knowledge-sharing in social systems are "rules of access," limiting the scope of exclusive rights. These rules take into account the multilateral social effects of IP rights.

The increasing number of privately crafted IP regimes indicates the social need for access rules that contribute to a robust environment for cultural knowledge-sharing. In more general terms, access rules are instances of "ecological integrity rules," which are developed in a decentralized way in civil society with the help of private law instruments (infra Part IV). Compensating for the lack of normative pluralism required by democratic constitutions, civil society occupies the law in order to preserve the environmental conditions of autonomy. However, this does not mean that the rationality of the law itself would have to surrender to the social norms embodied in standards and private regulatory regimes. In order to qualify as law, privately crafted norms have to meet the requirements of "public rules of recognition." Societal constitutionalism then unfolds through the recognition of the jurisgenerative power of societal rule production, together with the public role of private law in the judicial review of private ordering.

\section{INTERNATIONAL GOVERNANCE OF INTELLECTUAL PROPERTY}

\section{A. Subjecting Exclusive Rights to Exclusive Rationality}

Most of the international treaties in the field of IP law are designed to protect the economic rights associated with creative works. Focus lies on commercializing the use of works by granting exclusive rights to authors, inventors, and intermediaries. Although the rationale of international IP protection is therefore quite specific, this economic rationality is extended to a wide variety of possible uses. Clearly, the tendency of international treaties is to protect the economic rights comprehensively. The scope of control of IP rights was extended to ever more fields of use of the protected work. ${ }^{4}$ This excessive proliferation of IP rights is the expression of a "property logic," according to which all possible positive externalities of use are to be internalized, including future forms of use that are automatically subjected to the authority of

4. See Gustavo Ghidini, InNovation, Competition and CONSUMER Welfare in INTELLECTUAL PROPERTY LAW 33, 98 (2010) (describing developments in copyright and patent law). 
the rights holder. ${ }^{5}$ On the national level, such logic is, at least in principle, limited by the constitution because the economic interests of right holders must be balanced against the access interests of users in ways that reflect constitutional principles and rights of equal priority. In contrast, on the international level, the creation of IP rights can grow largely unchecked. Driven by the claims of strong lobby groups that often merge with the protectionist interests of states, IP rights proliferate in number and in scope. A system of checks and balances is not in place. Quite to the contrary, the public autonomy of users, who could raise their voices against excessive growth of exploitation rights, is held in check by the sovereignty of states in foreign affairs. A remarkable exception is the international protest of civil society against the Anti-Counterfeiting Trade Agreement (ACTA); that protest proved to be successful insofar as the European Parliament ultimately rejected the ratification. In this case, broad mobilization within-and beyond-the digital rights community created pressure to ignite public debate and render societal deliberation sensitive to competing interests. ${ }^{6}$

\section{B. The TRIPS-Framework: Linking IP to Trade}

The basic idea of international treaties in the area of IP is to provide effective protection to authors whose work is used abroad. Multilateral treaties among states compensate for the consequences of the principle of territoriality that limits an IP right to the territory of the state granting it. In the late nineteenth century, the major IP treaties-the Berne Convention for the Protection of Literary and Artistic Works from 1886 and the Paris Convention for the Protection of Industrial Property from 1883-were built around two basic principles: first, signatory states had to provide in their domestic law certain minimum levels of intellectual property protection ("substantive minima"); second, as a general rule, a signatory state was obliged to offer protection to

5. See also Michael A. Carrier, The Propertization of Copyright, in 1 INTELLECTUAL Property and Information Wealth: Issues and Practice in the Digital age: COPYRIGHT AND RELATED RIGHTS 345 (Peter Yu ed., 2007).

6. See, e.g., Thank You SOPA, Thank You ACTA, EUR. Digital RTS. (July 4, 2012), http://www.edri.org/edrigram/number10.13/good-bye-acta (commenting on the EU Parliament vote against ratification of ACTA). See generally Leonhard Dobusch \& Sigrid Quack, Framing Standards, Mobilizing Users: Copyright Versus Fair Use in Transnational Regulation, 20 REV. INT'L POL. ECON. 52, 71 (2013) (describing the actors and structures of the recent phase of political and social conflict over copyright). 
nationals of other signatory states that matched the protection it afforded its own nationals ("national treatment"). ${ }^{7}$

That is, although international copyright law required Member States to enact laws meeting certain minimum standards, the existence and scope of protection in any copyright infringement action is determined by the content of national law. ${ }^{8}$ Thus, under this model, Member States retain significant leeway to implement those standards in ways that remain consistent with their national legal traditions and their social, cultural, or economic priorities.

However, an early asymmetry in the international copyright regime needs to be noted. In the Berne Convention, only the minimum standard of protection was mandatory, whereas exceptions and limitations were discretionary and without any force in the absence of state action. ${ }^{9}$ This reflects the understanding of developed countries that the precise nature of such limitations was to be left to the reserved powers of the state to foster the welfare interests of its citizens. ${ }^{10}$ Even as the Convention matured and came to incorporate limitations that had evolved over time in a large number of states, it maintained its official deference to sovereign prerogative by making domestic compliance with the recognized limitations and exceptions voluntary.

This situation has changed remarkably since 1994 with the conclusion of the Agreement on Trade-Related Aspects of Intellectual Property Rights (TRIPS), which is administered by the World Trade Organization (WTO). TRIPS consolidated copyright protection with that of other IP rights in one comprehensive international document and strengthened its protection by building on top of the acquis of substantive provisions of the Berne Convention ("Berne Plus" approach). The most important aspect is that TRIPS introduced IP law into the international trading system. ${ }^{11}$ Stimulated on one side by the

7. See generally Graeme B. Dinwoodie, The Architecture of the International Intellectual Property System, 77 CHI.-KENT L. REV. 993, 994-99 (2002) (providing an overview of the classical legal regime of international IP law).

8. See Graeme B. Dinwoodie, The Development and Incorporation of International Norms in the Formation of Copyright Law, 62 OHIO ST. L.J. 733, 739 (2001).

9. See RUTH L. OKEDIJ, UNCTAD-ICTSD PROJECT ON IPRS AND SUSTAINABle DeVelopment, Issue PaPer No. 15, The InTERnational Copyright System: Limitations, EXCEPTIONS AND PUBliC INTEREST CONSIDERATIONS For DEveloping COUNTRIES 1,8 (2006).

10. See id. at 5. See also P. Bernt Hugenholtz \& Ruth L. Okediji, Contours of an International Instrument on Limitations and Exceptions, in THE DEVELOPMENT AGENDA: Global INTEllectual Property and Developing Countries 473, 474 (Neil Weinstock Netanel ed., 2008).

11. See Graeme B. Dinwoodie \& Rochelle C. Dreyfuss, A Neofederalist Vision of TRIPS: The Resilience of the INTERnational INTElleCtual Property Regime 7 (2012). 
increasing importance of copyright industries in the economies of developed countries, and, on the other side, by concerns about global piracy of IP made possible by digital technology and online distribution of content over the Internet, the leading countries of the developed world decided that these challenges could best be answered by subsuming international IP protection under the framework of trade relations. Under WTO/TRIPS, the international copyright legal order has become, in large part, enforceable. If a nation fails to fulfill international copyright obligations, this shortcoming may be met by the imposition of trade sanctions. In particular, the WTO's Dispute Settlement Understanding (DSU) provides for a binding resolution process bolstered by strong enforcement provisions. ${ }^{12}$

Due to these instruments, which make legal obligations effective, the WTO/TRIPS has had a much more profound influence on domestic lawmaking than prior IP treaties. In combination with the fact that the WTO forum allows for a faster development of international norms, so that new technological issues can be tackled proactively instead of just codifying what is a long standing consensus, the WTO/TRIPS framework has become the most influential legal source in international IP law.

Everything then seems to depend on whether TRIPS provides a sound and balanced framework for IP policy. Linking IP law to the agenda of free trade seems to limit IP lawmaking to an instrument of exploiting the comparative advantage in ownership of IP rights. Whether this concern is reasonable depends on the design of limitations and exceptions in TRIPS.

By virtue of Article 9(1) of TRIPS, Member States must ensure that their national laws conform to the norms contained in Articles 1-21 (excluding moral rights) of the last iteration of the Berne Convention. ${ }^{13}$ Under these provisions, Member States are permitted to limit the exclusive rights of copyright holders. These permitted uses could take different forms, such as constraints on the subject matter of copyright protection, ${ }^{14}$ uncompensated limitations in the form of exceptions to copyright infringement, ${ }^{15}$ or compensated limitations in the form of

12. See Myra J. Tawfik, International Copyright Law and Fair Dealing as a User Right, UNESCO E-COPYRIGHT BULL., Apr.-Jun. 2005, at 1, 8, http://unesdoc.unesco.org limages/0014/001400/140025e.pdf.

13. See id. at 1, 9-10, (explaining the interplay between TRIPS Articles 9(1) and 13 and the Berne Convention).

14. Agreement on Trade-Related Aspects of Intellectual Property Rights art. 2(4), 2(8), 2bis(1) B.C., Apr. 15, 1994, Marrakesh Agreement Establishing the World Trade Organization, Annex 1C, 1869 U.N.T.S. 299.

15. Id. at art. $2 \mathrm{bis}(2), 9(2), 10,10 \mathrm{bis} \mathrm{BC}$. 
compulsory licenses. ${ }^{16}$ These provisions are supplemented by the stand-alone provision of Article 13 TRIPS, which is modeled on Article 9(2) $\mathrm{BC}$ and defines limits on the discretion and means by which Member States can constrain the exercise of exclusive rights conferred either under the Berne Convention or under TRIPS itself. Every limitation or exception needs to comply with a three-step test stating: "Members shall confine limitations or exceptions to the exclusive rights to certain special cases which do not conflict with a normal exploitation of the work and do not unreasonably prejudice the legitimate interests of the right holder." 17 This test also made its way into Article 5(5) of the European Copyright Directive 2001/29/EC, which explicitly recognizes in recital (44) that the exceptions and limitations provided for in this Directive should be exercised in accordance with international obligations. ${ }^{18}$

\section{Problems of a Unilateral Economic Interpretation of the Three-Step Test}

Taking into account the importance of this test, it might be surprising that as of today there has been only one decision of an international adjudicative body interpreting either Article 13 TRIPS or Article 9(2) of the Berne Convention. In a dispute resolution proceeding, initiated by the European Union, a panel of the WTO in June 2000 held that Section 110(5)(B) of the U.S. Copyright Act, which exonerated all commercial establishments that broadcast music to the general public from copyright royalty payments, was not in conformity with the obligations of the United States under Article 13 of TRIPS. ${ }^{19}$ In comparison, the main impact of the three-step test on adjudication occurs at the national level, where the domestic courts are obliged to construe national legislation in accordance with the three-step test as part of international or supranational law. ${ }^{20}$ The reasoning of the Panel deserves special attention for two reasons. Since other international instruments, such as the 1996 World Intellectual Property Organization

16. Id. at art. $11 \mathrm{bis}(2)-(3), 13 \mathrm{BC}$.

17. Id. at art. 13.

18. Green Paper: Copyright in the Knowledge Economy, at 5, COM(2008) $466 / 3$ final (July 16, 2008) (affirming that the three-step test "has become a benchmark for all copyright limitations").

19. Panel Report, United States-Section 110(5) of the US Copyright Act, W'T/DS160/R I 6.1 (June 15, 2000).

20. See Case C-5/08, Infopaq Int'l A/S v Danske Dagblades Forening, 2009 E.C.R. I-6569 (demonstrating that the European Court was not required to consider Art 5(5) and the meaning of the Three-Step Test). 
(WIPO) ${ }^{21}$ Copyright Treaty ${ }^{22}$ and the WIPO Performers and Phonograms Treaty, ${ }^{23}$ as well as the supranational instrument of the mentioned EC Information Society Directive, ${ }^{24}$ have adopted the threestep test, the WTO Panel decision not only represents an important element of a truly transnational copyright law, but also demonstrates the problematic nature of the three-step test as an instrument for achieving a balanced copyright law on a transnational scale.

With regard to the second criterion, the Panel held that permitted uses are in conflict with "normal exploitation" whenever they enter into economic competition with the ways that right holders normally extract economic value from that copyright and thereby deprive them of significant or tangible commercial gains. ${ }^{25}$ To assess the impact of the exempted use, the Panel does not merely want to consider the forms of exploitation that currently generate revenue, but also those which in all probability are likely to be of importance in the future. ${ }^{26}$ Thus, the Panel expressly introduces a normative approach to defining normal exploitation that includes a dynamic element capable of taking into account technological and market developments in favor of the right holder. ${ }^{27}$ Consideration of both actual and potential effects on exploitation is motivated by the reasoning of other WTO panels, which stated that proof of actual trade effects was not an indispensable prerequisite for a finding of inconsistency with the national treatment clause of Article III of the General Agreement on Tariffs and Trade (GATT) where there was the potential of adverse effects on competitive opportunities for foreign products. ${ }^{28}$ Although the Copyright Panel was well aware that, as a result, it was going to interpret TRIPS in the light of concepts developed for GATT and the General Agreement on Trades and Services (GATS), it assumed the legitimacy to do so from the fact "that the agreements covered by the WTO form a single, integrated legal system."29

21. See WIPO, http://www.wipo.int/portal/index.html.en (last visited Sept. 30, 2013).

22. World Intellectual Property Organization Copyright Treaty art 10, Dec. 20, 1996, 36 I.L.M. 65 (1997).

23. World Intellectual Property Organization Performances and Phonograms Treaty art 16(2), Dec. 20, 1996, 36 I.L.M. 76 (1997).

24. Council Directive 2001/29, art. 5(5), 2001 O.J. (L 167) (EC) (" $[\mathrm{O}] \mathrm{n}$ the harmonisation [sic] of certain aspects of copyright and related rights in the information society.").

25. Panel Report, supra note 19 , at $\uparrow 6.183$.

26. Id. at I 6.180 .

27. $I d$. at $\$ 6.178$.

28. Working Party Report, Brazilian Internal Taxes, June 30, 1949, GATT B.I.S.D. II/181, 185, aff'd inter alia Panel Report, United States-Taxes on Petroleum and Certain Imported Substances, June 17, 1987, GATT B.I.S.D. 34S/136, 158.

29. Id. at \ 6.185 . 
From the perspective of a WTO panel, this approach makes perfect sense, as the agreements under the WTO umbrella need to be interpreted both consistently with each other and in the light of free trade, as the main thrust or idée directrice of this piece of international law. Yet, from the perspective of a balanced copyright scheme, "reference to future exploitations runs the risk of paralyzing exceptions every time a technical evolution allows [the] controlling of previously uncontrollable uses." 30 In the digital age, a "broader range of means of exploitation of copyright works becomes technically feasible, [so] the scope of the potential 'normal exploitation' of a copyright work correspondingly increases and, if a restrictive approach to the second step is adopted, the discretion of states (and courts) to maintain appropriately fashioned exceptions is" reduced. ${ }^{31}$ For instance, using a copyrighted work in digitized form could invoke a multiplicity of rights that were irrelevant to the personal use exception in the print context. If downloading copyrighted works to use for private research or other personal use requires the right of reproduction, display, performance, and/or distribution, the rights holder will argue that any translation of the personal use exception into the digital environment deprives him of a realizable commercial gain from the new uses involved. Indeed, some national courts have already invoked the three-step test in a manner that constrains the scope of national exceptions in the face of technological development, arguing that a potential loss of income arising as a result of digital modes of exploitation was sufficient alone to place a user's activities outside the scope of a statutory exception. ${ }^{32}$

This dynamic reading of "normal exploitation," which extends copyright to new forms of use, exactly matches the mentioned "property logic" in IP law. ${ }^{33}$ It precipitates a copyright maximalism because it forecloses a corresponding dynamic design of limitations in reaction to new technological and social developments. Thus, the present international adjudication of the three-step test under TRIPS unilaterally links the rationale of IP rights to the economic system.

30. Christophe Geiger, Implementing an International Instrument for Interpreting Copyright Limitations and Exceptions, 40 INT'L REV. INTELL. PROP. \& COMPETITION L. 627, 634 (2009).

31. Jonathan Griffiths, The "Three-Step Test" in European Copyright Law: Problems and Solutions, 4 INTELL. PROP. Q. 428, 441 (2009).

32. See Comment, France: Intellectual Property Code, Arts.L.122-5, L.211-3; Berne Convention, Art.9.2; Directive on the Harmonisation of Certain Aspects of Copyright and Neighbouring Rights in the Information Society - "DVD Copy III," 37 INT'L REV. INTELL. Prop. \& COMPETITION L. 760 (2006). Rechtbank Den Haag, March 2, 2005, case no. 192880, LJN AS8778, COMPUTERRECHT 143 (2005). For a comment on these decisions see id.

33. See infra Part I.A. 
The restrictive interpretation of the second step proposed by the Copyright Panel definitely frustrates the achievement of an effective balance between the protection of rights holders' economic interests and users' interests in access when taking into account the cumulative reading of the three steps, each being a separate and independent requirement that must be satisfied. According to the Panel, "[f]ailure to comply with any one of the three conditions results in the exception being disallowed." ${ }^{44}$ Such cumulative nature of the three-step test would aggravate the problem of a restrictive interpretation of the second condition since an infringement of the second step would necessarily foreclose any justification of the limitation under the third criterion, which requires the limitation to "not unreasonably prejudice the legitimate interests of the right holder." 35 Even if the third condition were construed in line with the equivalent tests contained in Article 17 of TRIPS (for trademark law) and Article 30 of TRIPS (for patent law), and even if it were thus possible to take into account not just the economic value of the exclusive right but also other legitimate interests (as the Copyright Panel declined to do), ${ }^{36}$ an examination of competing public interests underlying the limitation could simply not take place. As has been warned, there is a danger that the prohibition on all conflict with the "normal exploitation" of a work will assume undesirable "showstopped" status. ${ }^{37}$

To address this problem, various strategies have been proposed. One tries to lessen the restrictiveness of the second condition by proposing that a conflict with normal exploitation should only be assumed when uses covered by an exception make very substantial incursions into a copyright owner's potential market. ${ }^{38}$ Another idea is to extend the normativity of the second criterion beyond economic interests so that any limitation that accords with competing considerations of copyright law and its fundamental values would not conflict with a normal form of exploitation. ${ }^{39}$ Perhaps the approach most likely to be considered by a

34. Panel Report, supra note 19 , at $\uparrow 6.97$.

35. See Geiger, supra note 30 , at $636-38$.

36. See Panel Report, supra note 19, at \6.227 (explaining that the Copyright Panel confined interests to the economic value of the copyright).

37. See Kamiel J. Koelman, Fixing the Three Step Test, 28 Eur. InTELL. Prop. REv. 407, 410 (2006).

38. See Martin Senftleben, Towards a Horizontal Standard for Limiting Intellectual Property Rights?-WTO Panel Reports Shed Light on the Three Step Test in Copyright Law and Related Tests in Patent and Trademark Law, 37 INT'L REv. INTELL. Prop. \& COMPETITION L. 407, 437 (2006).

39. See Christophe Geiger, Jonathan Griffiths \& Reto M. Hilty, Declaration on a Balanced Interpretation of the "Three-Step Test" in Copyright Law, 39 INT'L REV. INTELL. 
future panel emphasizes "[t]hat the three-step test constitutes an indivisible" whole, with the consequence that "[t]he three steps are to be considered together and as a whole in a comprehensive overall assessment." 40 This way it seems possible to justify some prejudices in light of values deemed superior to the interests of the right holder. In fact, under such an approach the three-step test would be transformed into a proportionality test that in principle allows for a balance of economic and social interests.

However, even if it is possible to construe the three-step test in specific cases in a way that considers a legislator's intent for a diverse cultural domain, the test will always act as a "limit for limitations." 41 That is, the test is structurally biased in favor of economic interests because every proposed limitation has to be justified before the forum for the protection of economic exploitation. As a consequence of this built-in preference rule, conflicts of use that ultimately point to conflicts between different social rationalities are not modeled impartially under the trade framework. In contrast, under a national constitution the interests of rights holders, as well as those of users, can be linked to different fundamental rights that are, in principle, of equal normative weight.

In addition, TRIPS reduces the person of the rights holder to homo economicus, because it only deals with the economic exploitation of exclusive rights. In consequence, there is no room to differentiate between the creative author as the original right holder and professional exploitation entities as subsequent right holders. ${ }^{42}$ Although the interests of both types of right holders often concur, the concern of authors for the greatest possible dissemination of their works may sometimes advise protection through a liability rule instead of a strong property rule, which is preferred by subsequent right holders seeking to maximize their profit.

\section{THE EPISTEMOLOGY OF SOCIAL ORDER}

Absent the force of the national constitutions, state-made law is seemingly prone to a normative unilateralism. This diagnosis holds true not only in the area of IP law. Generally, in international law there is a

PROP. \& COMPETITION L. 707, 707 (2008), for "a declaration of experts that aims to confirm the legitimacy of a balanced interpretation of the 'three-step test."' Id.

40. Id. at 711 .

41. For this functional characterization of the test, see MARTIN SENFTLEBEN, COPYRIGHT, LIMITATIONS AND THE THREE-STEP TEST: AN ANALYSIS OF THE THREE-STEP TEST IN INTERNATIONAL AND EC COPYRIGHT LAW 1 (2004).

42. For a discussion of this differentiation see $i d$. at 708-09. 
tendency to develop "self-contained" legal regimes that are characterized by "international law's contractual bias: where a matter is regulated by a treaty, there is normally no reason to have recourse to other sources." 43 The normative program of treaties may then be exclusively subject to a specific social rationality, with the effect that the respective social autonomies are afforded protection from intervention by national policies. This amounts to the transnational extension of the liberal distinction between state and society and reinforces the commitment of political constitutions to restrain political power from encroaching on social autonomies. The idea of political constitutions, however, leaves open the question of constitutional rules for autonomous social rationalities other than the organized political system; the issue of how to limit social autonomies from expanding their specific rationalities to the detriment of other autonomies has been neglected in the past. It is, therefore, questionable whether the traditional idea of constitutionalism is really able to provide for the normative multilateralism required in modern differentiated society. As it appears, the shortcomings of the traditional model are caused by reducing the problem of social order to the issue of dealing with the phenomenon of power in social relations. The resulting fixation on the law of the state underrates the possibilities of a decentralized generation of order through social institutions that operate on the basis of property rights. Evolving from social norms, societal rules of property may then be regarded as the building blocks of alternatively created normative worlds that may be more in line with the needs of the different social spheres of meaning production affected by-and based on-IP rights.

\section{A. Models of Constitutionalism}

The problem of social order is attributed to Hobbes and his analysis of modern society. According to the political philosophy of Hobbes, society is composed of individuals that are driven by a plurality of passions. ${ }^{44}$ In addition, man is equipped with reason, but reason is only

43. Martti Koskenniemi, Fragmentation of International Law: Difficulties Arising from the Diversification and Expansion of International Law, Rep. of the Int'l Law Comm'n, 58th Sess., May 1-June 9, July 3-Aug. 11, 2006, ๆ 128, U.N. Doc. A/CN.4/L.682 (Apr. 13, 2006). In a broader sense, the term is used to refer to interrelated wholes of primary and secondary rules that cover some particular problem differently from the way it would be covered under general law. See id. at $\$ 123$.

44. See ThOMAS HoBBES, LEVIATHAN 39 (Richard Tuck ed,, 1991) (1651) ("But whatsoever is the object of any mans Appetite or Desire; that is it, which he for hi spart calleth Good... There being nothing simply and absolutely so; nor any common Rule 
a servant to passions. It is the faculty of devising ways and means to achieve what is desired but provides no restraining control of action. Given that actions of men are potential means to each other's ends and that power is the ability to command the actions of other men, the acquisition of power becomes a proximate end for each individual. However, if no limitations on the use of means exist, social relations would dissolve into an unlimited struggle for power in which the attainment of the ultimate, diverse passions would be impossible. ${ }^{45}$ To overcome this natural state of ubiquitous power wars, men agree by contract to cede their natural liberty to a sovereign authority that in turn guarantees them security through the monopoly of power acquired. Thus, society is conceived of as being ordered by accession to a social contract in favor of a single entity. ${ }^{46}$ This entity, itself not being party to the contract, automatically becomes a solitaire of power since all the parties divest themselves of a presumed ius in omnia et omnes. ${ }^{47}$ Hobbes teaches a lesson in institutionalization. However, this institutionalization is artificial; its creation by way of waiver results in epistemological emptiness. The central actor can do everything, but knows nothing, because aggregated knowledge of men remains in society.

Framed in such a way, the problem of social order appears as a problem of coping with power in society. The main idea is to concentrate the decentralized societal sources of power in an artificial body of sovereignty. Once created, the political body is expected to be able to normatively integrate society. 48

Political power is channeled "backwards" through society primarily by positive law as a medium. In a democratic state, the law is conceived of as being contingent on political will and receives its legitimacy from the legislative procedure. ${ }^{49}$ In principle, lawmaking is being centralized

of Good and Evil, to be taken from the nature of the objects themselves; but from the Person of the man").

45. See 1 TalcotT Parsons, The Structure Of Social ACtion 93-94 (1937).

46. See WolfGang Kersting, Die politische PhILOSOPhiE DEs Gesellschaftsvertrags [The Political Philosophy OF THE SOCIAL CONTRACT] 85 (1994) (Ger.) ("horizontal contract of subjection," translated).

47. See HoBbes, supra note 44, at 120 ("[I]t is a reall Unitie of them all, in one and the same person, made by Covenant of every man with every man, in such manner, as if every man should say to every man, I Authorise and give up my Right of Governing my selfe, to this Man, or to this Assembly of men, on this condition, that thou give up thy Right to him, and Authorise all his Actions in like manner.").

48. For a critique of Hobbes, see Jürgen Habermas, Law and Morality, in 8 THE TANNER LECTURES ON HUMAN VALUE 217, 269 (Kenneth Baynes trans., 1988).

49. This procedure in turn is constituted in the form of law. See JÜRGEN HABERMAS, BETWEEN FACTS AND NORMS: CONTRIBUTIONS TO A DISCOURSE THEORY OF LAW AND DEMOCRACY 110 (William Rehg trans., 1996), for such “democratic positivism." 
parallel to the monopolization of power. To be sure, the legal forum of the state knows individual rights as a source of law made by private actors. However, the rule of recognition, in the hands of the state, is thought to guarantee impartiality, since procedural universality springs from democratic generation of law as the expression of the "united will of the people." 50

Subjecting politics to democratic procedure is just one method of dealing with the follow-up problems of creating a specialized and independent (autonomous) sphere of collective decision-making. Policies also need to comply with the rule of law, which requires laws to take the form of general rules that are universally applied. ${ }^{51}$ Finally, the scope of issues that are exposed to politicization and regulation needs to be limited. In short, there must be safeguards that in turn limit the power of the autonomous center. The historical answer is the evolution of a constitution for the political body. Constitutions support the abstraction of state power as an autonomous social commodity, ${ }^{52}$ and, at the same time, restrain political power from pathologically expanding into social autonomies. Constitutions "create boundaries between politics and its social environ[ments]," most importantly with the help of fundamental rights. ${ }^{53}$

In sum, the traditional concept of constitutionalism is deeply linked to Hobbes's qualification of the problem of social order and how to deal with the use of force against others in rational pursuit of individual goals. The solution is to establish a central authority-the state-that normatively determines what is binding for each member of the collective. In the light of social contract theory, social cooperation is, in a way, rebooted by the law of the state. As the newly-constituted autonomy of the center is itself prone to being used in a self-expanding way (by falling victim to the logic of power), constitutions came to be installed as institutions for the self-limitation of this autonomy. However, this does not change the fact that the capacity for the generation of order is exclusively located in the state. Quite the contrary, the existence of constitutionalized politics appears to reaffirm the plausibility and necessity of a single collective order and a

50. See Immanuel Kant, MetaphysiK DER SitTen [Metaphysics of MoRals] § 46 (1870), for Kant's proposal of the criterion of universality as a test for the lawfulness of legal norms: whether a law could have arisen from the united will of an entire people.

51. See Friedrich A. HAYeK, The Constitution of Liberty 206 (1960), for information on the rule of law.

52. See Chris Thornhill, The Future of the State, in Financial CRISIS IN Constitutional Perspective: The Dark Side of Functional Differentiation 357 (Poul F. Kjaer, Gunther Teubner \& Alberto Febbrajo eds., 2011).

53. TEUBNER, supra note 2 , at 17 . 
centralized form of lawmaking. Political constitutionalism is founded on the idea that the essence of society is the law.

In contrast, societal constitutionalism challenges the premises of political constitutionalism. It opens up the perspective and puts the problem of social order in the context of social evolution. The unleashing of utilitarian rationality in society and the establishing of autonomous politics is just part of a general change in the evolution of society that now differentiates according to function (and not status). ${ }^{54}$ The autonomy of social spheres then gets multiplied, as does the problem of limitation of autonomies. In consequence, the traditional concept of constitutionalism becomes inadequate since it cannot come to grips with this plurality of idiosyncratic (and nonsubstitutable) social systems and with the loss of the state as a guarantor of multi-functional decision-making and normative integration at the global level.

To overcome this inadequacy, societal constitutionalism-in the account of Teubner-makes three distinguished moves: (1) applying a functional analysis to political constitutions, which allows for a generalization of the function of constitutions (i.e. the double function as a medium for stabilization of autonomy and limitation of this autonomy towards social environments); (2) expanding the analysis of processes of constitutionalization from the political order to other social orders (with the aim of transferring/re-specifying the insights of functional analysis to these orders); and (3) claiming that limitation of systemic autonomy can be effective only as internal self-limitation of the communicative medium (though initiated only through external pressure). ${ }^{55}$

Societal constitutionalism denotes the idea of coping with the problems of functional differentiation in a decentralized way. Given that every function system determines its own identity by an elaborated semantics of self-reflexivity, Luhmann concludes that the mutual dependencies of subsystems can no longer be subject to normative integration. ${ }^{56}$ Accordingly, there are no outside stop rules for the excessive growth of a particular subrationality (i.e. the maximalization of the society-wide impact of their communicative media) that may be in collision with other subrationalities or in collision with its own self-reproduction. ${ }^{57}$ Therefore, societal constitutionalism urges function

54. See Niklas Luhmann, Differentiation of Society, 2 CANADIAN J. Soc. 29, 45 (1977) (discussing the effects of functional differentiation).

55. See id. at 73.

56. See NikLas LuhManN, Die Gesellschaft DER GESELlSChaft [ThE COMPANY OF THE COMPANY] 745 (1997).

57. Growth gets pathologic and turns into destruction if it collides with other social dynamics. See TEUBNER, supra note 2 , at 81 , for information on who identifies. In addition to the two mentioned types of collisions, a third one is "the collision with a comprehensive 
systems to develop internal (self) limitations in analogy to the political system (separation of powers, rule of law, and fundamental rights). In the constitutionalization of social systems-a process that usually needs a lot of social energy-law plays a crucial role because it makes normatively binding a special type of reflexivity essential for the strategy of decentralized mastery of differentiation: the observation of itself as a system within an environment. 58 Taking on this function for a system requires that the law itself change its mode of operation. As it appears, the full range of consequences of the "cognitive turn" of social development implicated by functional differentiation-that norms no longer steer the prior selection of knowledge but that, conversely, the problem of learning adaptation acquires structural primacy ${ }^{59}$-has yet to be explored.

\section{B. Societal Rules of Property}

Both on the national and on the international level, binding rules on the use of resources belong to the kernel of social orders. Obviously, they must form an essential part of social contract theory since scarcity of natural resources gives rise to social conflict and fuels violent struggle for power. From Hobbes to Rousseau, the transition from the state of nature to civil government is, therefore, marked by the institutionalization of property rights that is intended to prevent violent conflict about the use of protected resources. In reality, though, this account of the origin of property is flawed with the stigma that the transition perpetuates the preexisting relationships of power. In consequence, the current scheme of distribution of private property must either be subjected to binding rules of natural law on appropriation (Locke's proviso) or be put at the disposal of the emergent common interest (volonté générale) of the newly-formed collective body (Rousseau). ${ }^{60}$ For Rousseau, the rationality of a social order is linked in the most extreme way to the precondition that particular interests are erased. The "real foundation of society" is the transcendence of the individuals into a new person with an emergent will.61 Management of

rationality of world society" (by assuming that the subsystems, from their decentralized perspective, were able to reflect on a macro-rationality).

58. On this type of social reflexivity, see infra Parts III.A. and IV.D.

59. See 2 NIKLAS LUHMANN, Die Weltgesellschaft, in SOZIOLOGISCHE AUFKLÄRUNG [Sociological ENLIGHTENMENT] 51, 63 (1975) (referred to in TEUBNER, supra note 2, at 94).

60. See JEAN-JACQUES RouSsEaU, SocIal CONTRACT ch. 6 (G. D. H. Cole trans., 1782) (discussing lawmaking in a republican state).

61. Jean-Jacques Rousseau, Émile ou De l'éducation, Livre V [Emile, or on Education, Book 5], in 4 OEUVRES COMPLETES [COMPLETE WORKS], 840 (1969) ("Chacun de nous met 
property rules is then put in the hands of the sovereign collective. Leaving aside the tension of any republican model of law with fundamental rights of the individual, this may be a convincing legitimation of governmental power. It does not answer how the collective body acquires the knowledge for tailoring property rules.

Social contract theory is based on constructivist rationalism. Only from here does one arrive at the idea of property as a legal construct within the order of a state (status civilis). An alternative account can be found with Hume, who conceives of property as being based on societal conventions. Legal rules, just as moral beliefs, are neither innate ideas nor conclusions of reason, he argues, but an outcome of practical experience, artifacts, and standards: "those impressions, which give rise to this sense of justice, are not natural to the mind of man, but arise from artifice and human conventions." 62 Law and morals arise gradually and establish in the course of time "general and inflexible" rules and principles that restrain the partiality of man. ${ }^{63}$ They acquire force not by contractual agreement but "by a slow progression, and our repeated experience of the inconveniences of transgressing it."64 In fact, rules of this sort (most importantly on the "stability of possession, its translation by consent, and the performance of promises") must be recognized before people can come to bind themselves by promise or contract to any form of government. ${ }^{65}$

In this view, property rules are the product of the evolution of cooperation. Other than in the social contract model, they may not be reduced to the negative function of preventing direct force and the peaceful execution of an existing social order. Rather, they are the expression of the evolution of conventions and social order. The main idea of Hume's critique of the social contract is that "the essence of society is not the law but rather the institution." 66 As a positive bundle of conventions on cooperation, property is only to be ensured by the

en commun ses biens, sa personne, sa vie et toute sa puissance, sous la suprême direction de la volonté générale, et nous recevons en corps chaque membre comme partie indivisible de tout.") ("Each of us puts his goods, his person, his life, and all his power in common under the supreme direction of the general will, and we as a body accept each member as a part indivisible from the whole.").

62. See 3 David Hume, A Treatise of Human Nature 496 (L.A. Selby-Bigge ed., 1896).

63. See id. at 532 .

64. See id. at 490 . However, if the national IP rules in force are being derogated, no inconveniencies seem to be the result, but rather an increase in productive cooperation.

65. See F.A. HAYEK, supra note 3 , at 114 .

66. GILlES DELEUZE, EMPIRICISM AND SUBJECTIVITY 45 (Constantin V. Boundas trans., 1991); see also HUME, supra note 62, at 501 (describing the "establishment of the rule, concerning the stability of possession, be not only useful, but even absolutely necessary to human society"). 
state but not constituted ${ }^{67}$ The legislator should not be regarded as the one who legislates, "but rather first of all the one who institutes." 68 The task of the legislator, then, is not to affirm some preexisting natural rights but to affirm social conventions. The focus of normative analysis then shifts to institutions as models of action. In this sense, social normativity precedes the law.

The consequence of replacing a constructivist concept of property by an evolutionary account of the rise of law is a kind of epistemological turn of the problem of social order. If the law must be assumed to process a model of normativity that is dependent on the cooperation of a whole network of cognitive and practical conventions and patterns of behavior, ${ }^{69}$ then the social function of rights is to be seen in the generation of generalizable experience as a positive externality to individual decision-making. In turn, the legitimacy of rights consists in the possibility of the individual deriving personal advantage from experience stored in iterations of artificially-constituted relations. Knowledge is dispersed among a multitude of individuals and their social practice, and so it can likewise only be made accessible through decentralized decision-making rights. Accordingly, property rules imply practical knowledge as processed in society. They do not operate as instruments to execute social order. Order emerges in the way that actions and rules are tested and decentralized and the resulting patterns are reflected.

By emphasizing the epistemological dimension of property rights, private law comes to the forefront automatically. Private law provides the normative instruments to make social standards binding and enforceable; it may promote, as well as put limits on, the jurisgenerative force of standards. This is of special importance in the realm of intellectual property, where the exercise of property rights has repercussions for cultural and scientific evolution. Here, the law by necessity influences not only the generation of economic knowledge, since protection is extended to the media of communication that are constitutive to processes of knowledge sharing in other social systems. To understand the peculiar problem of constitutionalizing knowledge-sharing, the multilateral social effects of IP rights must first be elucidated. This will be the ground from which it becomes clear how

67. See the excellent analysis of Hume's notion of property in Ino Augsberg, Ohne Gesetz kein Eigentum? [Without Law, No Property?], 11 RECHTSGESCHICHTE [LEGAL HISTORY] 94, 99 (2007).

68. DELEUZE, supra note 66 , at 46.

69. See Karl-Heinz Ladeur, The Postmodern Condition of Law and Societal "Management of Rules." Facts and Norm Revisited, 27 ZEITSCHRIFT FÜR RECHTSSOZIOLOGIE [JOURNAL OF SOCIOLOGY OF LAW] 87, 92 (2006). 
legal reflexivity must be conceived to make sure that property rights are construed in a way that ensures the integrity of knowledge-sharing in the multiplicity of social environments of the law.

\section{THE CONSTITUTIONALIZATION OF KNOWLEDGE-SHARING}

\section{A. A Relational Account of Intellectual Property Rights}

The specific challenge the legal regulation of intellectual goods is faced with can be adequately grasped only with a look to the interdependencies between the communicative activity of the individual and the corresponding cultural fields of activity. From the perspective of systems theory, this is a matter of the services that psychical and social systems provide for one another. The concept of "interpenetration" describes how different systems reciprocally provide their complexity to one another for the evolution of their own structures. ${ }^{70}$ Usually, IP scholarship attributes innovation to the creativity of the "individual," ignoring that not just systems theory, but other disciplines such as philosophy of language, discourse theory, and deconstructionism describe this same individual as highly socially mediated and, in many respects, decentered. ${ }^{71}$

Accordingly, it is essential for IP theory to develop instruments that consider the specific context of reproduction in which creative works and new knowledge arise. It is necessary to take appropriate account of cumulative knowledge, as well as the need to supply basic knowledge resources that are freely useable by all participating actors. Both factors can vary depending on the communication system, the generation of knowledge, and on the conditions of the functioning of the concrete institution of knowledge-sharing within which the collective creation of knowledge occurs (e.g. markets, firms, and networks).

To acknowledge the character of intellectual works as social constructs, IP law should be reconstructed on the basis of a genuine relation of communication and consciousness. More precisely, communication and consciousness must be understood as each other's necessary environment. The development and innovative capacity of cultural or scientific discourse can be explained only if such

70. See NikLas Luhmann, Social Systems 213 (John Bednarz, Jr. \& Dirk Baecker trans., 1995).

71. This is confirmed by research showing that authorship in the sense as this term is understood today is neither natural nor inevitable, but a relatively recent phenomenon that began to take shape in the eighteenth century. See Martha Woodmansee, The Genius and the Copyright: Economic and Legal Conditions of the Emergence of the 'Author', 17 EIGHTEENTH-CENTURY STUD. 425, 426-27 (1984). 
communications are viewed as forming systems in an environment that in turn arises out of centers of complexity structured by other (individual psychic) systems whose complexity can be gained for a system with the forms of law. The question of how to co-opt individual consciousness for the purpose of creating systemic knowledge defines the problem of "knowledge-sharing." 72

One form in which this co-optation of individual capacities for social systems actually happens is through the granting of property rights to persons. But that is not the whole story. If intellectual products become the subject of property rights, this also leads to a peculiar inter-relation of the cognitive environmental conditions of at least two function systems: In order to activate the market as a process of search and coordination, ${ }^{73}$ the possibilities of structural coupling between psychic systems to other social systems are subjected "at the behest" of the economic system to the control of the rights holder. ${ }^{74}$ The possibilities of inclusion, feasible on the basis of the nonrival use of intangible goods, are limited to fewer structural couplings than are possible.

Through the deliberate creation of exclusive rights in relation to the use of intellectual goods for the sake of artificially introducing scarcity in them and thereby enabling economic competition for them, markets gain significance for knowledge-sharing in other systems; conversely, and this is likely to be overlooked, the functioning of markets themselves then depends on the preservation of the epistemic conditions of the functioning of other systems. If the law gives the knowledge-sharing of a system to markets "as a fief," it, at the same time, forces the functional conditions of markets into new dependencies. ${ }^{75}$

72. See DAN WielsCh, ZugangSREgELN: Die RECHTSVERFASSUNG DER WiSSENSTEILUNG [Access Rules: The Legal ConstTtution of KNowledge Sharing], 31 (2008) (Ger.) (providing a detailed account of the relational theory of IP law).

73. See generally F.A. HAYEK, Competition as a Discovery Procedure, in NEW STUDIES in PHILOSOPHY, POLITICS, ECONOMICS AND THE History OF IDEAS 179 (1978).

74. See WIELSCH, supra note 72 , at 4.

75. Competition law is especially aware of this nexus in its concern for the social process of competition. The guaranteeing of competition in the distributed creation of new knowledge results not merely from the guaranteeing of property rights. The constant provision of a repository of publicly useable knowledge and information is equally important in the functioning of competition. What has been overlooked by Hayek is the dialectics involved when property rights are created for the sake of competition over intellectual products: Precisely because competition is installed to spur on creativity and to further innovation in cultural production, competition becomes dependent on the conditions of knowledge-sharing in cultural domains. Competition is not an "autarchic" stand-alone process but withers, as it were, when explicit knowledge cannot be recombined with distributed tacit knowledge. 
When the form of property is applied to the regulation of the use of intangibles that possess a communicative function, the law is placed within a challenging matrix of system-references and needs to organize its own forms so that the institutions of knowledge-sharing are supported in the economy as well as in the arts, science, technology, and other specialized discourses. It has to take seriously the multiplicity of social references of legal rights. Rights shape the environmental conditions for autonomous operations of various systems of meaning production, the autonomy of which translates into normative claims.

Acknowledging the social multi-referentiality of rights should be nothing new in IP law. Since its inception, copyright law has had to deal with the difference between moral rights related to the personality of the author and his economic interests. The approach proposed here asks IP law to continue developing this impulse of internal differentiation in response to multiple environmental requirements and to consequently consider all of the relevant social references of IP rights.

This extension of the law's horizon to the social dimension of legal forms is not an end in itself. The exercise of individual rights brings with it the emergence of trans-individual orders. Since these collective orders in turn decide the actual conditions for exercising individual autonomy, the effects that the exercise of rights bear on these social orders present a normative problem for the law. If the social effect of private law is left unattended, then the law cannot be "adequate" to its environment, and it ultimately fails to achieve justice. ${ }^{76}$

\section{B. Rules of Access: Environmental Reflexivity of Law}

To enable as well as to preserve the sharing of knowledge essential for diverse social discourses, the law not only needs to provide for exclusive rights, but also for "access rules" that fix the conditions under which users enjoy the freedom to use protected material without depending on the permission of the right holder. ${ }^{77}$ The law needs to acknowledge that the functional conditions of these systems include the requirement of adequate possibilities for permission-free use of works. Actually, the co-opting of consciousness for the purpose of creating systemic knowledge ("knowledge-sharing") must be based on two pillars of legal institutionalization: on the one hand, this co-optation proceeds

76. See generally Gunther Teubner, Self-Subversive Justice: Contingency or Transcendence Formula of Law?, 72 MOD. L. REv. 1, 8 (2009) (outlining an "ecological" extended notion of justice).

77. Though access need not necessarily be for free, but may be contingent upon the payment of adequate compensation in which the right holder has a mandatory participation. 
by way of instituting exclusive rights of use that grant individuals the chance to exploit the work on the market (so that they can cover the costs for their qualified "participation" in the respective discursive system); at the same time, the authority over the medial instantiations of meaning may not prevent the actualizability of the new systemic knowledge (through other individuals) to such an extent that further creative variation in the system is inhibited. ${ }^{78}$ The exclusive allocation of possibilities of use to a particular person deprives others from exploring these possibilities; the freedom of users is normatively restricted. By putting limits on such limitations of the freedom of users, access rules prevent the exercise of rights to intellectual goods from undermining the necessary conditions for the creation of those goods. In short, access rules decentralize the authority to select the use of an intellectual resource. They move selection authority to the observation capacity of users. ${ }^{79}$ This way, they preserve the environmental conditions of knowledge-sharing in social systems.

Notably, the economic system itself does recognize the necessity of limiting the propertization of use of intellectual goods. Economics, the reflection theory of the economic system, attentively observes the problems that result from a proliferation of IP rights for the internal rationality of the economic system. The restriction of the freedom of use is perceived as a loss of static effieciency resulting from the under-use of a resource, but also in its negative effects on dynamic efficiency. 80 Economists have very clearly formulated the dilemma of the privatization of intellectual goods from the perspective of the economy: "In a free-enterprise economy, inventive activity is supported by using the invention to create property rights; precisely to the extent that it is successful, there is an underutilization of the information." 81 The problem with IP rights is that they inhibit positive externalities of use, and inhibition of positive externalities occasions social costs. This insight suggests economic limits for the creation and scope of intellectual property rights according to a calculus of transaction costs and property-rights analysis ("economic proviso"). From the perspective

78. See WIELSCH, supra note 72 , at 63.

79. For a definition of property rights according to which they assign to particular individuals the authority to select, for specific goods, any use from a nonprohibited class of uses, see Armen A. Alchian, Some Economics of Property Rights, 30 IL Politico 816, 818 (1965).

80. See Yochai Benkler, A Political Economy of the Public Domain: Markets in Information Goods Versus The Marketplace of Ideas, in EXPANDING THE BOUNDARIES OF InTELLectual Property: InNovation POLICY for the KNOWLEDGE SOCIETY 267, 271 (Rochelle Cooper Dreyfuss et al. eds., 2001).

81. Kenneth J. Arrow, Economic Welfare and the Allocation of Resources for Invention, in COLLECTED PAPERS OF KENNETH J. ARROW 104, 112 (1985). 
of the reflection theory of the economic system, rules are required to restrict rights holders' exclusion right. ${ }^{82}$ To be sure, the nature and number of these restrictions may not go far enough from the perspective of society as a whole. The knowledge dilemma as noticed in information economics only points to access rules from a system-specific perspective.

The societal environment of the law expects justified legal rules that determine where the boundaries of the authority of IP rights are to be drawn. The law is thus checked for whether it contains internal "stop rules," and whether it has developed a kind of "sense for publicness" with regard to the protection of semantic constructs that exist only as media artifacts. ${ }^{83}$ The search for limitations of IP rights within the legal system itself is thus to be characterized as an "ecological" question, for it is ultimately aimed at the system's relationship with its environment. ${ }^{84}$

In principle, all of the social references of rights, which represent normative claims of the different social spheres for autonomy, are of equal priority. In the context of national IP regimes, this is affirmed by the fact that constitutions contain a plurality of fundamental rights that all enjoy the same normative weight. Therefore, the constitution provides the legislator with sufficient normative support for creating a wide variety of access rules, mainly in the form of statutory limitations that could be responsive to the characteristics of knowledge-sharing in different institutions and social systems. However, the legal corridor in which nation states are entitled to create limitations autonomously is significantly restricted by the requirements of international treaties, especially by the three-step test. As mentioned, international law produces a multitude of legal regimes that are self-contained and only host a specific normativity. ${ }^{85}$ Given the great impact of the trade regime

82. For limitations on the creation of property rights in general, see Harold Demsetz, Toward a Theory of Property Rights, 57 AM. ECON. REV. 347, 350 (1967) ("[P]roperty rights develop to internalize externalities when the gains of internalization become larger than the cost of internalization."). However, only recently the economic analysis of law came to recognize that the social costs associated with the creation of intellectual property rights comprise opportunity costs resulting from the inhibition of positive externalities. See Brett M. Frischmann \& Mark A. Lemley, Spillovers, 107 CoLUM. L. REV. 257, 299-301 (2007).

83. See WIELSCH, supra note 72, at 51.

84. Ecological sensitivity of the law can be achieved on different theoretical grounds, too. See generally James Boyle, A Politics of Intellectual Property: Environmentalism for the Net?, 47 DUKE L.J. 87 (1997) (pioneering the idea to transfer insights on environmentalism to the field of IP policy); see also James Boyle, Cultural Environmentalism and Beyond, 70 LAW \& CONTEMP. PROBS. 5 (2007) (a comprehensive valuation of Boyle's concept of "cultural environmentalism").

85. This is described as the replacement of territoriality by functionality as the principle of social differentiation. See Fragmentation of International Law: Difficulties Arising from the Diversification and Expansion of International Law, supra note 43, at 133. 
and its preference for economic interests, the following question arises: how can the law take care of other social rationalities when it is called upon to decide legal disputes?

\section{Debugging the Three-Step-Test: Connecting TRIPS with Horizontal Normativity}

In response to the economic logic of the WTO scheme and the corresponding interpretation of Article 13 of TRIPS by the Copyright Panel, a broader approach is called for. It may consist in contextualizing the rights and obligations of TRIPS within other international treaties. In fact, Article 31(3)(c) of the Vienna Convention even requires taking into account "any relevant rules of international law applicable in the relations between the parties." 66 With regard to the plurality of fundamental values underlying copyright law, this especially suggests considering international human rights. ${ }^{87}$ Such interplay between economy-focused international copyright law and international legal sources that aim to protect other values may substitute for the lack of a coherent set of fundamental rights backing different social autonomies as is known from the national constitutions. Different normativities would then be imported from the outside into the context of WTO-hosted copyright law. With respect to the socio-cultural dimension of copyright law, Article 27 of the Universal Declaration of Human Rights and Article 15 of the International Covenant on Economic, Social and Cultural Rights (ICESCR) were suggested as provisions that could, for instance, guide a broader normative approach in interpreting the respective steps of Article 13 of TRIPS. 88 Both provisions recognize the right of the individual to participate in cultural life and thereby emphasize the importance of access to copyrighted material. ${ }^{89}$ In addition, Article 15 of the ICESCR requires states to let this right become effective through sustainable protection of the domains of

86. See Vienna Convention on the Law of International Treaties, May 23, 1969, 1155 U.N.T.S. 331.

87. See Laurence R. Helfer, The New Innovation Frontier? Intellectual Property and the European Court of Human Rights, 49 HARV. INT'L L.J. 1 (2008).

88. See Geiger, supra note 30 , at 635 .

89. See International Covenant on Economic, Social and Cultural Rights, G.A. Res. 2200A (XXI), at Art. 15, U.N. Doc. A/RES/2200 (Dec. 16, 1966) ("The States Parties to the present Covenant recognize the right of everyone: (a) To take part in cultural life"); see also Universal Declaration of Human Rights, G.A. Res. 217 (III) A, at Art. 27(1), U.N. Doc. A/RES/217(III) (Dec. 10, 1948) ("Everyone has the right freely to participate in the cultural life of the community, to enjoy the arts and to share in scientific advancement and its benefits"). 
science and culture. ${ }^{90}$ Inside the normative body of TRIPS, Article 7 and 8 could function as "docking stations" for receiving the normative mandate of these external provisions: Article 7 of TRIPS ties the protection of IP rights to the "mutual advantage of producers and users of technological knowledge" in a manner conducive not just to economic but also to "social welfare." 91 Article 8 of TRIPS authorizes Member States to adopt measures for the promotion of "the public interest in sectors of vital importance to their socio-economic and technological development."

However, one should not be too optimistic about the readiness of WTO panels to adopt such an "embedded reading" of TRIPS. In the end, it depends on the trade forum itself to admit the external normativities. The least one can expect is for the single member states to review the three-step test and "soften" it by transforming it into some kind of rule of reason that allows for a balance of interests in an impartial way. Since state law, therefore, does not seem able to develop access rules at the global level that could keep in pace with the globalization of function systems, constitutionalization of knowledge-sharing in the sense explained rather takes place through the initiatives of private actors.

\section{SOCIETAL IP REGIMES}

There is strong evidence that the provisions in international IP treaties alone do not satisfy the demands of knowledge production in society and the various types of social interaction requiring the use of copyrighted material. In the years after the conclusion of TRIPS, it turned out that the WTO and the World Intellectual Property Organization (WIPO), the two big institutional actors in international IP policy, are not the only authors of IP rules with a de facto global reach. IP lawmaking on a global scale also occurs-among others-in "the practices of multinational information industry actors"; in the adjudication of "national courts [that are beginning to develop] a private international law of intellectual property"; in the constraints digital "technology that operates without regard to territory" ("code is law"); in transnational operating NGOs; and in the activities of new actors who cooperate in transnational networks. 92

90. See International Covenant on Economic, Social and Cultural Rights, supra note 89, at Art. 15(2) ("The steps to be taken by the States Parties to the present Covenant to achieve the full realization of this right shall include those necessary for the conservation, the development and the diffusion of science and culture.").

91. See Geiger, supra note 30, at 628-29.

92. Graeme B. Dinwoodie, The International Intellectual Property Law System: New Actors, New Institutions, New Sources, 10 MARQ. INTELL. PROP. L. REV. 205, 205 (2006). 
Perhaps the most unexpected development in recent years is the increase of privately-crafted IP regimes. In copyright law, examples include Open Source Licensing Models (e.g. GNU-GPL), Open Content Licensing Models (e.g. Creative Commons), Massive Multi-Author Collaboration Sites (e.g. Wikipedia), Extended Collective Licenses (e.g. in the Scandinavian countries), Quasi-Contractual Licenses (e.g. the proposed Google Book Settlement Agreement), and Copyright Collection Societies (e.g. the GEMA in Germany). In patent law, one could refer to Patent Pools (e.g. DVD6C, MPEG-2 Patent Portfolio License, SARS corona virus pool), Standard License Clearinghouses (e.g. Science Commons), Open Source Genetics (e.g. CAMBIA's BiOS License), and access and benefit sharing systems (e.g. in ECCO).

In particular, private IP regimes emerge in the course of collaborative knowledge projects. Here, contributors share the work of generating piecemeal knowledge and make openly available the outputs of their efforts for others to use. "Such collaboration can evolve when a [complex design] task can be partitioned into smaller modules that can be worked on independently," in parallel, or successively. ${ }^{93}$

\section{A. Redirecting Legal Form}

To interact according to the peculiar operational logic of the project, contributors use "open licensing models" that constitute project-specific commons. These models share one main idea: building on their exclusive rights granted by territorial copyright, creators make use of their private autonomy and extend the scope of permitted uses beyond the limitations of statutory IP law. Each contributor to the project irrevocably grants to everyone in the public broad rights to use his or her contribution. 94

The legal instrument by which the individual contribution is levied for the sake of the common interest in the project is the "copyleft" provision that requires each creative user of the publicly licensed work to license his follow-on contribution in turn under the same open license terms. ${ }^{95}$ This provision and the other terms of the open license are to be

93. Dan Wielsch, Governance of Massive Multiauthor Collaboration: Linux, Wikipedia, and Other Networks: Governed by Bilateral Contracts, Partnerships, or Something in Between?, 1 J. INTELL. PROP. INFo. TECH. \& E-COM. L. 96 (2010) (discussing the operational logic of knowledge projects).

94. In copyright, for example, this permission can extend to the right to copy, the right to distribute, and the right to modify the work.

95. See GNU General Public License, Version 2, § 2(b), GNU OPERATING SYSTEM (JUNE 1991), http://www.gnu.org/licenses/gpl-2.0.html (last visited Feb. 9, 2013), which contains a typical copyleft: "You must cause any work that you distribute or publish, that in whole 
regarded as conditions of the copyright license. If the licensee fails to comply with these conditions, then the licensor can bring an action for copyright infringement. 96 With the help of this "socio-legal hack," the exclusive right is not waived, but its function is reversed from the safeguarding of the prerogatives of the author to the safeguarding of the freedoms of the user. ${ }^{97}$ As a result, the right to use the contribution is decentralized as if a statutory limitation were to apply.

This is the genius of copyleft: due to the fact that now many users can decide independently on the use of one and the same resource, the chances for its creative employment-for a follow-on-creation-are multiplied. The private crafting of a commons moves the authority to select to the knowledge of the individual user. Thereby networks of open collaboration ingeniously combine the epistemic qualities of markets and firms: they spur on a discovery procedure among a dispersed multitude of independent actors-pretty much the same way as in markets; yet, at the same time, the access of these individual actors to resources is extended to much more than a single person would have at hand-pretty much the same way as in firms.98 Private licensing models, whether using the copyleft or different instruments, allow for tailoring access rules according to the logic of knowledge-sharing in different social discourses.

\section{B. Standards and Normative Orders}

To understand the social logic of nonstate IP regimes, it has to be considered that private access rules become legally binding with the help of standard licenses. Standards are the building blocks for private property regimes. The license as such is of no social power; even the power of the viral license constituted by the copyleft is due to the standard terms that commit everybody to adopt the same open access policy. Open licenses are not the expression of individual preferences, but form part of emergent social structures that are institutionalized to different degrees. As such, standards have a significant public dimension that is constituted by their power to control social

or in part contains or is derived from the Program or any part thereof, to be licensed as a whole at no charge to all third parties under the terms of this License."

96. See Jacobsen v. Katzer, 535 F.3d 1373 (Fed. Cir. 2008), for an example of a U.S. court affirming the terms of the license.

97. See WIELSCH, supra note 72 , at 211.

98. More precisely, access to resources is the same as in very big firms because, quoting Eben Moglen: "If the GNU GPL were a firm, it would be the single largest software development firm in the world, far larger than Microsoft." Patrice-Emmanuel Schmitz, Public Development: Interview With Professor Eben Moglen, SYNERGY, Jan. 2006, at 10 . 
institutions. In the case of IP regimes, standards often determine behavior in the institution of the network. A more familiar institution that can be influenced through standards is, of course, the market. ${ }^{99}$ In the case of collaborative networks, new types of cooperation and emergent social structures are enshrined into standard licenses.

As such, the licenses themselves are nested in broader normative orders, especially in conventions among the participants of epistemic projects and communities. True, open source software licenses, for example, can be interpreted not only as technical legal terms of use for certain software but also as the expression of standards for cooperation. The license, in this respect, operates as a social contract: "In the absence of hierarchical authority, the license becomes the core statement of the social structure that defines the community of open source developers who participate in a project." 100 On the other hand, the license terms cannot be conceived of as a stand-alone social structure. This becomes clear from the difficulties legal doctrine experiences when it tries to capture the obligation to open back-licensing of the user's own contribution in traditional categories. The paradigm of private law is constituted by dyadic reciprocity. The copyleft, in contrast, embodies a kind of abstract reciprocity that is committed to maintaining the openness of the source code, thereby guaranteeing the integrity of the specific process of knowledge-sharing. Such reciprocity can be explained only against the background of the four fundamental freedoms that are to be granted to the user of free software ("the freedom to run it, to study and change it, and to redistribute copies with or without changes"); they constitute the ethical underpinning of the GNU General Public License. ${ }^{101}$

\section{Self-Institutionalization of Discursive Rationality}

The normativity of the four freedoms is closely linked to the operational logic of knowledge projects. In this context, Hobbes' problem is just put aside. As mentioned, Hobbes thought of social order as the management of power. He was unaware of the epistemological dimension of social institutions. In the context of project-based

99. See Dan Wielsch, Global Law's Toolbox: Private Regulation by Standards, 60 AM. J. COMP. L. 1075, 1080 (2012).

100. Steven Weber, The Success of OPEn Source 179 (2004).

101. See Richard Stallman, Why Open Source Misses the Point of Free Software, GNU OPERATING SYSTEM, http://www.gnu.org/philosophy/open-source-misses-the-point.html (last visited Feb. 2, 2013) ("Open source is a development methodology; free software is a social movement. For the free software movement, free software is an ethical imperative, because only free software respects the users' freedom."). 
knowledge sharing activities, his reasoning needs to be turned upside down. Here, institutionalization builds on knowledge. The management of knowledge requires leaving knowledge where it resides and providing it with authority. Knowledge is to be entitled. In fact, the four freedoms establish a different social basis. "These freedoms are vitally important. They are essential, not just for the individual users' sake, but for society as a whole because they promote social solidarity - that is, sharing and cooperation."102 The abstract reciprocity of the copyleft preempts strategic action so that activities can concentrate on the generation of new expert knowledge in the respective discursive network. This way, the functional logic of cultural or scientific projects can take guidance of social cooperation. Socialization, then, does not take place through purposive rationality nor through communicative rationality, but through the operative logic of the respective discourses-through systems rationality. Ultimately, the normativities of social systems craft property regimes.

As it seems, the evolution of private property regimes indicates that social systems directly author access rules at the global level. Access rules develop in close responsiveness to the functional logic of specific projects and the respective practices of knowledge sharing. Territorially-differentiated IP law is replaced by social conventions of use. Among the consequences of the "cognitive turn" of social development implicated by functional differentiation, as diagnosed by Luhmann, would then be the decentralization of lawmaking. In a similar way as the rights of use in networks are moved to the individual capacity of knowledge-recombination (since transfer of knowledge would be very difficult in practice), so too the authority of lawmaking must be decentralized and afforded to private regimes governing the use of intellectual goods. They can be much closer to the functional and contextual conditions of knowledge-sharing than a legislator. ${ }^{103}$

102. Id.

103. However, the scope of involvement of the political system-as compared to an internal politicization of functional systems-may vary depending on the subject area. On the constitutionalization of transnational standard-setting in corporate financial accounting as "controlled interaction of economy and politics through legal means" see Moritz Renner, Occupy the System! Societal Constitutionalism and Transnational Corporate Accounting, 20 IND. J. GLOBAL LEGAL STUD. 941, 964 (2013) (regarding the structural coupling of the transnational lawmaking process to the political system as defining for constitutionalization). Regularly, processes of constitutionalization would then be trilateral in nature, involving structural couplings between law, politics, and the respective system. 
In fact, private lawmaking by contractual standards can even lead to normative worlds that are in conflict with legislation. ${ }^{104}$ The teleological vision of an alternative normative world then stipulates a different order between values as compared with the preference rules of the state law. ${ }^{105}$ The privileged official norms generated by acts of state interpretation are dethroned by interpretive commitments of private communities and networks. ${ }^{106}$ The development of open licenses clearly shows how social movements are able to inflict different normative visions on the law and create counter-institutions to incumbent legal practice. Thus, the transformative power is not immanent to private law as such, but depends on stout commitment in creating legal meaning that, in turn, seems propelled by the clash of social rationalities in modern individuals. When state law claims jurisdiction in such a situation of challenge by an alternative configuration of rights and duties, it must be sensitive to these alternative legal regimes, since at the heart of law's own rationality is the idea of impartiality that requires the law to frame the questio iuris with due regard to all sources of normative meaning. 107

Therefore, the equivalent for the obligation of the constitution to equally protect all autonomies from the excesses of politics is the decentralized development of "ecological integrity rules," i.e. rules that

104. See, e.g., Authors Guild v. Google Inc., 770 F. Supp. 2d 666 (S.D.N.Y. 2011) (concerning the project of Google Books that inter alia tries to set up a legal regime for the use of orphan works. The access rights Google must claim for this arguably transcend the scope of fair use. The pending class action of affected authors resulted in an Amended Settlement Agreement the approval of which was denied by the court on March 22, 2011). For an analysis of the legitimacy of the proposed private copyright regime, see Wielsch, supra note 99 . What remains troubling, though, is the fact that the private entity claiming the new rights is not a social movement but a very powerful corporation. However, it is up to the law to develop recognition rules that ensure that private actors, while autonomously pursuing their own interests, do so simultaneously in/for the general interest.

105. See Robert M. Cover, Nomos and Narrative, 97 HARV. L. REv. 4, 45 (1983) (the creation of legal meaning ["jurisgenesis"] requires a "commitment to projecting the understanding of the norm at work in our reality through all possible worlds unto the teleological vision that the interpretation implies"). Essential for relating these visions to the normative precepts are narratives: they are the models by which the transformations can be studied "that result when a given ... state of affairs is made to pass through the force field of a ... set of norms," and by doing so they "integrate not only the 'is' and the 'ought', but the 'is', the 'ought', and the 'what might be."' Id. at 10.

106. See id. at 7 ("The normative universe is held together by the force of interpretive commitments-some small and private, others immense and public. These commitments-of officials and of others-do determine what law means and what law shall be.").

107. See Dan Wielsch, Relational Justice, 76 LAW \& CoNTEMP. ProBs. 191 (2013), for a discussion on the extension of law's impartiality to social autonomies. 
protect the integrity of system-specific knowledge-sharing from being subjected to the expansive rationality of another system. For example, by acknowledging the enforceability of open licensing models, the law protects knowledge-sharing in arts and science from being enslaved by the expansive logic of the economy. If one buys into the functional analysis of constitutionalism, then this reframing of the constitution only seems to be consequent: if the challenge is to protect social autonomies against each other (and not just against the encroachments of politics), then the constitutional function unfolds into decentralized rules on the constitution and limitation of autonomies. In a societal constitutionalism, the constitution gets dispersed into multilateral ecological integrity rules.

\section{Developing Public Rules of Recognition for Societal Normativity}

In this perspective, societal constitutionalism unfolds where legal forms get "socialized" when civil society appropriates the law in order to preserve the environmental conditions of autonomy. Socialization of legal forms implies that social normativities seize or "occupy" the institutional dimension of the law: the law is used to change the law itself. Social autonomies acquire rights to lawmaking. In a strange loop, external normativity suddenly comes from within the law. External pressure transforms into internal rupture of the law; "a reinterpretation of existing legal rights can effectively challenge prevailing practice."108 Socialization of law unfolds through dismantling the state's monopoly of meaning.

However, this does not mean that the rationality of the law would have to surrender to the social norms embodied in standards and private regulatory regimes. To qualify as law that claims society-wide validity for each situation the norms are applicable to, the privately-crafted norms have to meet the requirements of "public rules of recognition." 109 In other words, alternative normative worlds are required to engage with existing ones. The focus is, then, not so much on

108. Martha Minow, Interpreting Rights: An Essay for Robert Cover, 96 YALE L.J. 1860, 1902 (1987). See Emilios Christodoulidis, Strategies of Rupture, 20 LAW \& CRITIQUE 3, 6 (2009), for a discussion on the strategic use of "rupture" as a form of immanent critique revealing the contradictions of state law (in his opinion, identifying contradictions in the terms and discourses of the law is transformative in the sense that it "does not restore, but transcends, the 'disturbed' framework within which it arose"). For a caveat to the processes of constitutionalization, see Emilios Christodoulidis, On the Politics of Societal Constitutionalism, 20 IND. J. GLOBAL LEGAL STUD. 629 (2013), arguing that constitutionalism bears the danger to operate as deadlock to legal reform.

109. See Wielsch, supra note 99, at 1095-1100 (discussing public rules of recognition for private legal regimes). 
the origin of the norm (public or private), but on whether it meets the substantial requirements of a general rule of lawmaking. Maybe the essential question for both kinds of normative orders-statist and private-is how to ensure that private actors, while autonomously pursuing their own interests, do so simultaneously in/for the general interest. 110

The specific requirements will have to vary with the extension of the normative claim of the private standards and their actual public impact that can consist of third-party effects or even the control of social institutions. ${ }^{111}$ On the other hand, existing rules of recognition cannot remain unchanged when faced with these claims. In turn, they have to be innovated to do justice to private orders and their autonomous normative claims. On both sides, the private as well as the public, it is not just a question of exercising private autonomy and of granting it respectively. Matters are more complex. For instance, where the private lawmaking process is open and strives for balanced rules in a multitude of relationships, state law cannot just refer to the usual limitations of private autonomy and simply dismiss rules with third-party effects. Another important factor is the public function of the sector-specific regime; it would have to be affirmed especially in cases where the private regime can be interpreted to consist of ecological integrity rules. The public rules of recognition are then prompted to acknowledge this normative quality and, in consequence, to grant "concessions of autonomy ... . subject to [requirements and] reserved review ([especially with regard to] criteria, venues/fora, procedures)."112 It is necessary and legitimate to ask the normativity of public rules to reconsider itself because

no closed, correct, substantive ('rational', 'natural') concept is to be imposed against a 'false' reality, nor should any reality seek to arrogate an idea of its correctness, but 'society' (as being restrictively open and

110. See Rudolf Wiethölter, Zum Fortbildungsrecht der (richterlichen) Rechtsfortbildung [Back to the Training of Law (Court) Legal Education], 3 KRITTSCHE VIERTELJAHRESSCHRIFT FÜR GESETZGEBUNG UND RECHTSWISSENSCHAFT [THE CRITICAL QUARTERLY MAGAZINE FOR LEGISLATION AND JURISPRUDENCE] 1, 22 (1988).

111. For details see Dan Wielsch, Global Law's Toolbox: How Standards Form Contracts, in REGULATORY COMPETITION IN CONTRACT LAW AND DISPUTE RESOLUTION (Horst Eidenmüller ed., 2013).

112. For a discussion of the concept of admissability of freedoms see Rudolf Wiethölter, Just-ifications of a Law of Society, in PARADOXES AND INCONSISTENCIES IN THE LAW 65, 71 (Oren Perez \& Gunther Teubner eds., Iain L. Fraser trans., 2006). 
capable of learning) is, on the basis of previous experience, to be exposed to new experience. ${ }^{113}$

This is affirmed by a relational account of justice that resolves the impartiality of law into the obligation to evaluate the social multi-referentiality of rights and that makes binding the consideration of all sources of normative meaning. ${ }^{114}$

Ultimately, societal constitutionalism, therefore, requires a specific understanding of law. The reflexivity of the law must be able to "learn" ecologically from the different couplings to its normative environments. A learning self-reflexivity of the law then has to focus on the conditions of the "jurisgenerative" processes in society. ${ }^{115}$ It acknowledges the claims of private actors for self-regulation by opening up public normativity for realizing innovative new modes of social action and, at the same time, sets out requirements that oblige private rulemaking to reflect on public interest. This might indicate the necessity of an updated conception of political autonomy under conditions of decentralized lawmaking: the right to self-government would have to be reconceived as the right to justification of alternative normative worlds, met through evolving rules of recognition. ${ }^{116}$

When Hume started to make corrections of his works after publication, he changed "laws" into "rules of society" where this seemed advisable to make his meaning clear. ${ }^{117}$ Societal constitutionalism may be expected to agree. However, its approval relies on celebrating the public function of private law.

113. Rudolf Wiethölter, Proceduralization of the Category of Law, in CRITICAL LEGAI Thought: AN AMERICAN-GERMAN DEBATE 501, 507 (Christian Joerges \& David M. Trubek eds., 1989).

114. See Wielsch, supra note 107.

115. See Paul Schiff Berman, Global Legal Pluralism: A JuRisprudence of LaW BEYOND BORDERS (2012), for an expanded conception of jurisgenerative processes at the international and the global level.

116. For a discussion on the basic moral right to justification see Rainer Forst, The Justification of Human Rights and the Basic Right to Justification: A Reflexive Approach, 120 ETHICS 711, 719 (2010).

117. See Raymond Klibansky, Appendix to HUme, Theory of Politics 246 (Frederick Watkins ed., 1951). See also HAYEK, supra note 3, at 118-19 (referring to Klibansky's compilation of the corrections). Cf. FRIEDRICH A. HAYEK, Die Rechts- und Staatsphilosophie David Humes [The Rights-and Philosophy of David Humes], in Freiburger STUdien [Freiburg STUdies] 246 (1969) (Ger.) (where the reference to Klibansky's corrections is more clear). 